THE RISE AND FALL OF THE LABOUR LEFT 


\section{THE RISE AND FALL OF THE LABOUR LEFT}

PATRICK SEYD

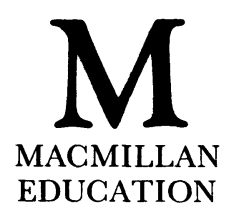


(C) Patrick Seyd 1987

Softcover reprint of the hardcover 1st edition 1987

All rights reserved. No reproduction, copy or transmission of this publication may be made without written permission.

No paragraph of this publication may be reproduced, copied or transmitted save with written permission or in accordance with the provisions of the Copyright Act 1956 (as amended), or under the terms of any licence permitting limited copying issued by the Copyright Licensing Agency, 33-4 Alfred Place, London WC1E 7DP.

Any person who does any unauthorised act in relation to this publication may be liable to criminal prosecution and civil claims for damages.

First published 1987

Published by

MACMILLAN EDUCATION LTD

Houndmills, Basingstoke, Hampshire RG21 2XS

and London

Companies and representatives

throughout the world

Typeset by Wessex Typesetters

(Division of The Eastern Press Ltd)

Frome, Somerset

British Library Cataloguing in Publication Data

Seyd, Patrick

The rise and fall of the labour left.

1. Labour Party, Great Britain-

History

I. Title

324.24107'09 JN1129.L32

ISBN 978-0-333-44748-2 ISBN 978-1-349-18923-6 (eBook)

DOI 10.1007/978-1-349-18923-6 
To Benjamin, Dan and Rachel 


\section{Contents}

List of Tables viii

Preface $\quad \mathrm{x}$

1. Introduction: Labour and its Left 1

2. The Breakdown of Social Democratic Consensus 18

3. Shifts in the Rank and File 37

4. National Organisation and Leadership 76

5. The Labour Left's Achievements at National Level 100

6. The Labour Left's Achievements in Local 137

7. Left Disintegration and Decline 159

8. Assessment 172

Postscript 187

Appendix: Survey 192

Notes 197

Sources $\quad 225$

Index 232 


\section{List of Tables}

3.1 Successful Left candidates' votes as a percentage of the total vote in the GLP section

3.2 Total individual Party membership 41

3.3 NEG votes for Militant candidates 53

3.4 Deselection of Labour MPs, 1970-80 54

3.5 Social class in Hallam and Attercliffe 63

3.6 Individual Party membership in Hallam and Attercliffe

3.7 Organisations represented by delegates to the General Committee

3.8 Year of joining the Labour Party 66

3.9 Age of Party members 66

3.10 Gender of Party activists 67

3.11 Type of schooling 67

3.12 Highest educational qualification 67

3.13 Present employment position 68

3.14 Type of employer of those in full-time work 69

3.15 Social class of Party activists in full-time work $\quad 69$

3.16 Type of housing $\quad 69$

3.17 Attitudes towards Clause 4 70

3.18 Attitudes towards nationalisation 71

3.19 Attitudes towards unilateral nuclear

3.20 Attitudes towards NATO 72

3.21 Attitudes towards private schools $\quad 72$

3.22 Attitudes towards private health care 72

3.23 Attitudes on breaking the law 73

3.24 Attitudes on voluntary prices and incomes policy $\quad 73$

4.1 Tribune MPs' dissenting votes 80

4.2 Membership of CLPD: 1974-86 87

4.3 CLPD Finance (Income and Expenditure):

1977-86 88

4.4 Tony Benn's membership of the NEC'1962-85 98 
5.1 GLPD-sponsored Resolutions to Labour Party Conference

5.2 Votes cast for constitutional amendments at Labour Party Conference, January 1981

5.3 Distribution of Party opinion on reselection

5.4 Distribution of Party opinion on the election of Party Leader

5.5 Distribution of Party opinion on the Election Manifesto

5.6 Characteristics of deselected Labour MPs

5.7 Deputy Leadership Election 1981

5.8 Election of Deputy Leader

6.1 Labour's electoral support in local elections 1973-86 


\section{Preface}

This study of the Labour Left has taken a long time to complete and as a consequence I have built up a considerable number of personal debts over the years. I am pleased to acknowledge the initial financial support provided by the Social Science Research Council (as it was then named). As a mature student with family commitments I could not have afforded to return to academic study without its support. I would also like to acknowledge the confidence which Professors Bernard Crick and Royden Harrison, both at Sheffield University in the late 1960 s, expressed in my research potential. I learnt from them the necessary interrelationship between thought and action. Both of them have made important contributions to political debate and have campaigned for radical change and I am proud to be part of that tradition in Sheffield.

I owe thanks to very many people in the Labour Party who have given freely of their time. Very rarely did anyone refuse to talk to me. Their generosity and hospitality is a reflection of all that is good on the Labour Left. It would be invidious to mention just a few names, and some asked not to be publicly identified, and therefore I thank them all in general terms.

I would like to acknowledge the assistance and advice of Leo Beckett, David Beetham, Henry Drucker, Alan Haworth, Arthur Lipow, Jean McCrindle and Anne Pettifor who all read and commented on parts of the text. Alan Tennant and Ken Simons gave generously of their time and provided considerable assistance and advice on the Party activist survey. The University of Sheffield Research Fund provided funds for part of the survey. In spite of other pressing demands on her time Marg Jaram retained her calmness and typed the complete text with speed and great efficiency.

I owe a particular debt of gratitude to three persons. For almost twenty years Lewis Minkin has shared his knowledge with me, stimulated me with his wide-ranging ideas, and 
encouraged me at a time when I felt like abandoning the project. The fact that I have completed this study is due in large part to his consistent support and friendship.

My only regret is that Jim MacFarlane is not alive to see the end-product. For twenty-five years he was my closest friend. He encouraged me to move to Sheffield and continue with my studies. I learnt an immense amount from him about South Yorkshire and its mining communities. Above all I benefited from his constant probing of fundamentals. He was one of the finest representatives of the British labour movement.

Most important of all I owe a very considerable debt of gratitude to my wife Rosalind, who interrupted her own career in order that I could continue with my studies. She encouraged me in difficult times and the final product is a small repayment for her continuous support and commitment. Our children Benjamin, Dan and Rachel - have grown up with this project. I hope it has not put them off Labour politics for life! I dedicate this book to them in the confidence that if the Labour Left succeeds in building popular support their lives will be safer and more pleasant.

I should add that all the people mentioned have contributed greatly but I alone am responsible for the interpretations. 